\title{
Alternating Degradable Copolymers of an Ionic Liquid-Type Vinyl Ether and a Conjugated Aldehyde: Precise Synthesis by Living Cationic Copolymerization and Dual Rare Thermosensitive Behavior in Solution
}

\author{
Daichi Yokota, Arihiro Kanazawa, and Sadahito Aoshima*
}

Department of Macromolecular Science, Graduate School of Science, Osaka University, Toyonaka, Osaka 560-0043, Japan

E-mail: aoshima@chem.sci.osaka-u.ac.jp

\section{Contents:}

Figure S1. Time-conversion curves, $M_{\mathrm{n}}$ and $M_{\mathrm{w}} / M_{\mathrm{n}}$ for polymer peaks, and MWD curves of products obtained by copolymerization of CEVE with pClBzA and their hydrolysis products

Figure S2. ${ }^{1} \mathrm{H}$ NMR spectrum of the product obtained by the polymerization of CEVE and pMeBzA

Figure S3. MWD curves of products obtained by copolymerization of CEVE with pCIBzA and their hydrolysis products

Scheme S1. The mechanism of the generation of a cyclic trimer.

Table S1. Introduction rates of imidazolium moieties into the side chains of precursor copolymers with various conjugated aldehydes

Table S2. Alternating copolymers of $\left[\mathrm{Me}_{2} \mathrm{Im}\right]\left[\mathrm{BF}_{4}\right]$ and conjugated aldehydes (for Figure 4A)

Table S3. Copolymers of $\left[\mathrm{Me}_{2} \mathrm{Im}\right]\left[\mathrm{BF}_{4}\right]$ and pClBzA (for Figure 4B)

Figure S4. Turbidity measurements of acetone solutions of poly $\left(\left[\mathrm{Me}_{2} \mathrm{Im}\right]\left[\mathrm{BF}_{4}\right]-\right.$ alt-pClBzA$)$

Figure S5. Effects of the additional salts on the thermosensitivity of poly $\left(\left[\mathrm{Me}_{2} \mathrm{Im}\right]\left[\mathrm{BF}_{4}\right]-\right.$ altpClBzA) in acetone, turbidity measurements of $0.8 \mathrm{wt} \%$ acetone/MEK solutions of poly $\left([\mathrm{MeIm}]\left[\mathrm{BF}_{4}\right]\right.$-alt-pClBzA$)$, and effects of additional ketones on phase separation temperature.

Table S4. Solubility characteristics of alternating copolymers of ionic liquid moieties with different counteranions and $\mathrm{pClBzA}$

Figure S6. Turbidity measurements of $1 \mathrm{wt} \%$ THF solution of poly([MeIm] $\left[\mathrm{NTf}_{2}\right]$-alt-pClBzA) and $0.4 \mathrm{wt} \%$ acetone solutions of poly $\left([\mathrm{R}]\left[\mathrm{BF}_{4}\right]\right.$-alt-pClBzA$)$ with different cations $\left(\mathrm{R}=\mathrm{Me}_{2} \mathrm{Im}\right.$, MeIm, and EtIm)

Figure S7. ${ }^{1} \mathrm{H}$ NMR spectra of poly(IBVE), poly(IBVE)- $b$-poly(CEVE-alt-pMeBzA), and the hydrolysis product of the copolymer

Scheme S2. One-shot synthesis of a block copolymer consisting of poly(CEVE) and poly(CEVE-alt-pMeBzA) segments.

Figure S8. Time-conversion curves, $M_{\mathrm{n}}$ and $M_{\mathrm{w}} / M_{\mathrm{n}}$ for polymer peaks, and MWD curves of products obtained by copolymerization of CEVE with pMeBzA and the hydrolysis product

Figure S9. ${ }^{1} \mathrm{H}$ NMR spectra of poly(CEVE-alt-pMeBzA)- $b$-CEVE and its hydrolysis product

Figure S10. Thermosensitive behavior for $4 \mathrm{wt} \%$ aqueous solutions of poly([ $\left.\left.\mathrm{Me}_{2} \mathrm{Im}\right]\left[\mathrm{BF}_{4}\right]\right)$, poly $\left(\left[\mathrm{Me}_{2} \operatorname{Im}\right]\left[\mathrm{BF}_{4}\right]-\right.$ alt-pMeBzA$)-b$-poly $\left(\left[\mathrm{Me}_{2} \mathrm{Im}\right]\left[\mathrm{BF}_{4}\right]\right)$, and poly([Me $\left.\mathrm{Im}_{2}\right]\left[\mathrm{BF}_{4}\right]$-alt-pMeBzA$)$

Figure S11. DLS measurement for $0.3 \mathrm{wt} \%$ acetone solution of poly(IBVE)- $b$-poly([ $\left.\mathrm{Me}_{2} \mathrm{Im}\right]\left[\mathrm{BF}_{4}\right]$-alt-pMeBzA) 

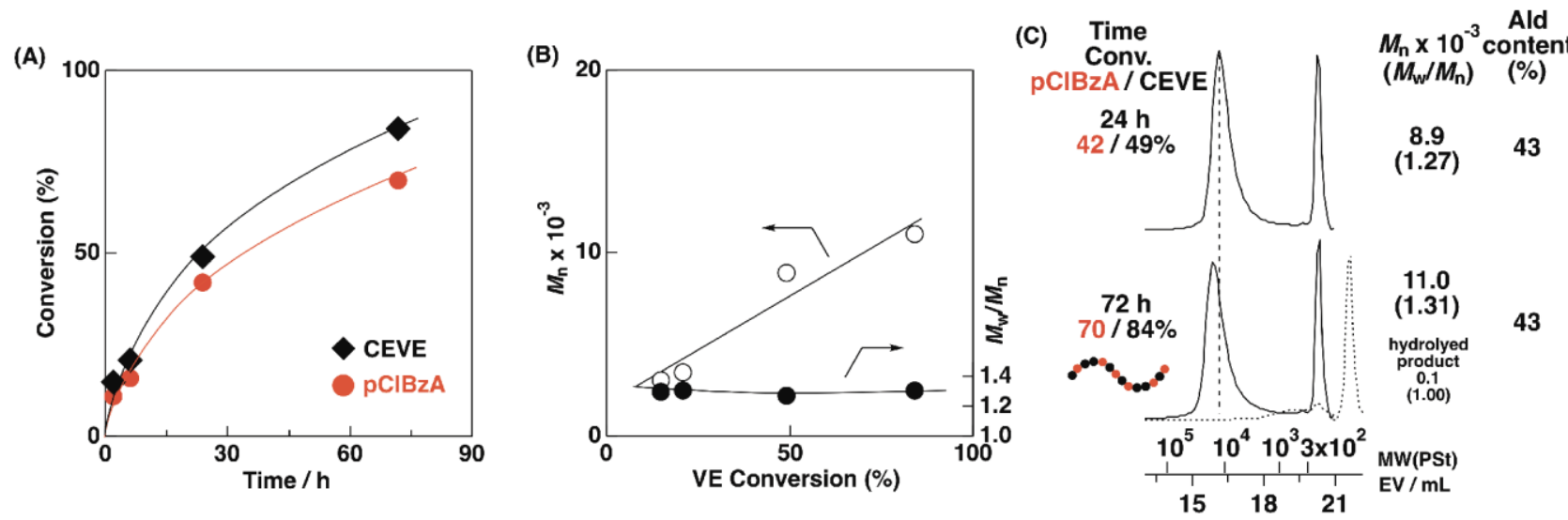

Figure S1. (A) Time-conversion curves, (B) $M_{\mathrm{n}}$ and $M_{\mathrm{w}} / M_{\mathrm{n}}$ for polymer peaks, and (C) MWD curves of products obtained by copolymerization of CEVE with pClBzA (solid curves) and their hydrolysis products (dotted curves) (polymerization conditions: $[\mathrm{CEVE}]_{0}=0.60 \mathrm{M}$ and $[\mathrm{pClBzA}]_{0}$ $=0.60 \mathrm{M}\left[\mathrm{EtSO}_{3} \mathrm{H}\right]_{0}=4.0 \mathrm{mM},\left[\mathrm{GaCl}_{3}\right]_{0}=4.0 \mathrm{mM},[1,4$-dioxane $]=1.0 \mathrm{M}$ in toluene at $-78^{\circ} \mathrm{C}$; hydrolysis conditions: $0.50 \mathrm{M}$ aqueous $\mathrm{HCl}-\mathrm{DME}$ at $30^{\circ} \mathrm{C}$ for $2 \mathrm{~h} ; 0.50 \mathrm{wt} \%$ polymer solution).

Note for Figure S1: The controlled alternating-like cationic copolymerization of CEVE and pClBzA also proceeded using the $\mathrm{EtSO}_{3} \mathrm{H} / \mathrm{GaCl}_{3}$ initiating systems at $-78{ }^{\circ} \mathrm{C}$. pClBzA had the lowest reactivity among the aldehydes used in this study due to the electron-withdrawing chlorine atom at the $p$-position of the aromatic ring. In the copolymerization of CEVE and pClBzA (entries 7 and 8 in Table 1), both monomers were almost simultaneously consumed, yielding copolymers with relatively narrow MWDs (Figure S1A and S1B). ${ }^{1} \mathrm{H}$ NMR analysis of the copolymers indicated that acetal moieties derived from a crossover reaction from CEVE to pClBzA were observed, while that peaks for the pClBzA-pClBzA sequence were not observed. The aldehyde content of the copolymer was $43 \%$. The result indicates that the copolymer with CEVE and pClBzA had an alternating-like sequence. However, the aldehyde content was lower than those of the copolymers with pMeBzA or pMeOBzA (entries 3-6 in Table 1) because the homopropagation reactions of CEVE partially occurred because of the lower reactivity of pClBzA. A cyclic trimer was also formed from two pClBzA units and one CEVE unit. The amount of this byproduct was approximately $10 \%$ of the obtained copolymers, as calculated by ${ }^{1} \mathrm{H}$ NMR (Figure S2). 


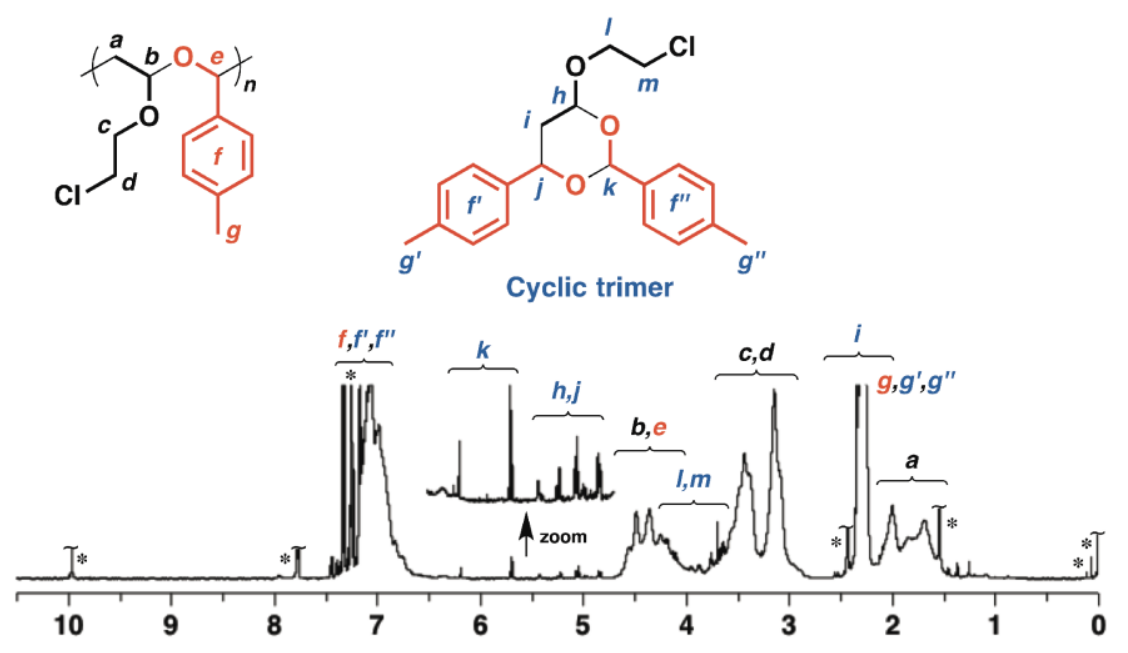

Figure S2. ${ }^{1} \mathrm{H}$ NMR spectrum of the product obtained by the polymerization of CEVE and pMeBzA (before purification by reprecipitation; a polymer obtained under the same conditions to those for Figure 2); * TMS, grease, water, and residual pMeBzA monomer.
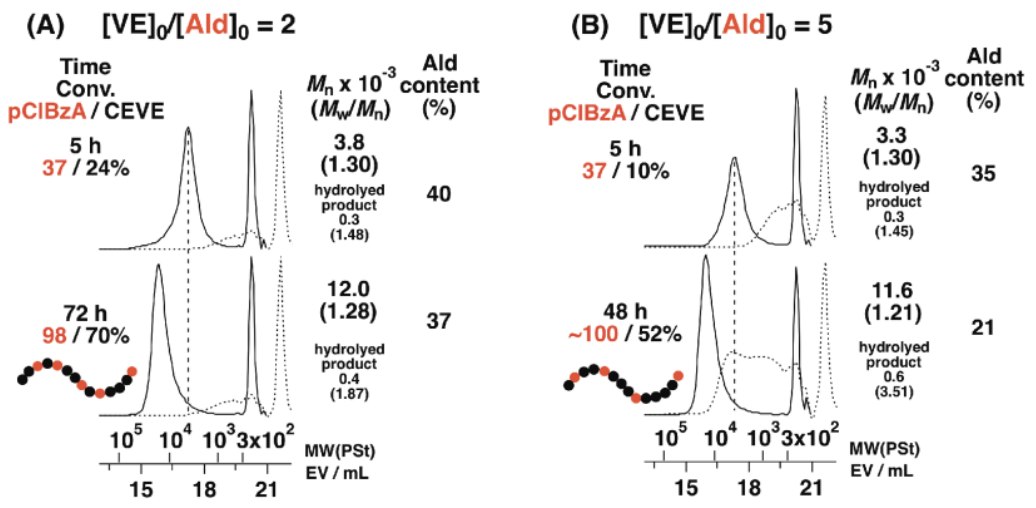

Figure S3. MWD curves of products obtained by copolymerization of CEVE with pClBzA (solid curves) and their hydrolysis products (dotted curves) (polymerization conditions: $(\mathrm{A})[\mathrm{CEVE}]_{0}=$ $0.80 \mathrm{M}$ and $[\mathrm{pClBzA}]_{0}=0.40 \mathrm{M}$ and $(\mathrm{B})[\mathrm{CEVE}]_{0}=1.0 \mathrm{M}$ and $[\mathrm{pClBzA}]_{0}=0.20 \mathrm{M},\left[\mathrm{EtSO} \mathrm{H}_{0}=\right.$ $4.0 \mathrm{mM},\left[\mathrm{GaCl}_{3}\right]_{0}=4.0 \mathrm{mM},[1,4-$ dioxane $]=1.0 \mathrm{M}$ in toluene at $-78{ }^{\circ} \mathrm{C}$; hydrolysis conditions: $0.50 \mathrm{M}$ aqueous $\mathrm{HCl}-\mathrm{DME}$ at $30^{\circ} \mathrm{C}$ for $2 \mathrm{~h} ; 0.50 \mathrm{wt} \%$ polymer solution).

Note for Figure S3A: Copolymers with different pClBzA contents were synthesized at different feed ratios of CEVE and pClBzA. A copolymer with a $37 \%$ aldehyde content, which is lower than the alternating-like copolymer, was obtained at a CEVE/pClBzA feed ratio of $2 / 1$ ([CEVE] $]_{0}=0.80$ $\mathrm{M},[\mathrm{pClBzA}]_{0}=0.40 \mathrm{M}$; Figure $\mathrm{S} 3 \mathrm{~A}$ ). Acid hydrolysis of the copolymer was conducted to investigate the copolymer sequence because the copolymer has acetal moieties derived from the crossover reaction from $\mathrm{CEVE}$ to $\mathrm{pClBzA}$ in the main chain. The hydrolysis products were a cinnamaldehyde derivative, which is derived from CEVE-pClBzA-CEVE sequences, and oligomers of CEVE, as suggested by ${ }^{1} \mathrm{H}$ NMR. The generation of the CEVE oligomers was also confirmed by a broad peak in the low MW region on the GPC chart (the dotted curves, Figure S3A). In addition, the amount of the CEVE oligomers in the hydrolysis product of the copolymer with a pClBzA content of $37 \%$ was larger than that of $43 \%$ (Figure S1C). The result indicates that the former copolymer had more CEVE-CEVE linkages. 
Note for Figure S3B: To obtain gradient-like copolymers of CEVE and pClBzA, copolymerization was conducted at a higher feed ratio of CEVE/pCIBzA than that in the above cases. The copolymerization with the CEVE amount five times larger than the pClBzA amount yielded copolymers that had relatively narrow MWDs. The MWs of the copolymers increased with an increase in VE conversion. The aldehyde content calculated from the ${ }^{1} \mathrm{H}$ NMR spectra of the obtained copolymers gradually decreased, such as 35\%, 30\%, 21\%, and 13\%, as the copolymerization progressed. The data indicates the gradual decrease in the instantaneous compositions of the pClBzA units in the polymer chain (Figure S3B). In addition, the products obtained via the acid hydrolysis reaction of the copolymers of $21 \%$ aldehyde content had a wider MWD than those of the copolymer with a higher aldehyde content. Therefore, the copolymer of $21 \%$ aldehyde content had a gradient-like sequence.

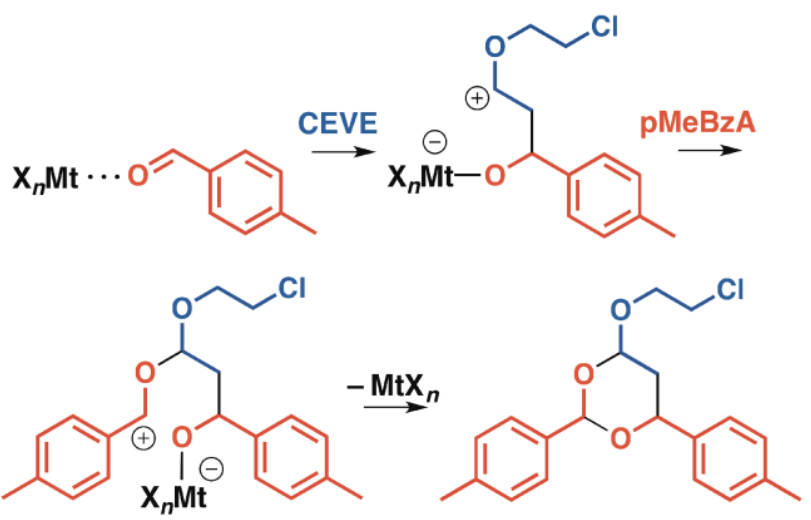

Scheme S1. The mechanism of the generation of a cyclic trimer.

Table S1. Introduction rates of imidazolium moieties into the side chains of precursor copolymers with various conjugated aldehydes ${ }^{a}$

\begin{tabular}{|c|c|c|c|}
\hline entry & Copolymer & $\begin{array}{l}\text { Imidazolium } \\
\text { moiety }\end{array}$ & $\begin{array}{c}\text { Aldehyde } \\
\text { content }\end{array}$ \\
\hline 1 & $\operatorname{poly}\left(\left[\mathrm{Me}_{2} \operatorname{Im}\right]\left[\mathrm{BF}_{4}\right]-\right.$ alt $\left.-\mathrm{BzA}\right)$ & $\sim 100 \%$ & $41 \%$ \\
\hline 2 & poly $\left(\left[\mathrm{Me}_{2} \operatorname{Im}\right]\left[\mathrm{BF}_{4}\right]-\right.$ alt-pMeBzA $)$ & $\sim 100 \%$ & $49 \%$ \\
\hline 3 & poly $\left(\left[\mathrm{Me}_{2} \mathrm{Im}\right]\left[\mathrm{BF}_{4}\right]-\right.$ alt-pMeOBzA$)$ & $\sim 100 \%$ & $50 \%$ \\
\hline 4 & $\operatorname{poly}\left(\left[\mathrm{Me}_{2} \mathrm{Im}\right]\left[\mathrm{BF}_{4}\right]-\right.$ alt-pClBzA$)$ & $96 \%$ & $42 \%$ \\
\hline
\end{tabular}

${ }^{a}$ Determined by ${ }^{1} \mathrm{H}$ NMR spectra of copolymers. 
Table S2. Alternating copolymers of $\left[\mathrm{Me}_{2} \mathrm{Im}\right]\left[\mathrm{BF}_{4}\right]$ and conjugated aldehydes (for Figure 4A)

\begin{tabular}{ccccc}
\hline polymer & line & $\begin{array}{c}M_{\mathrm{n}} \\
(\mathrm{GPC}) \\
\times 10^{-3}\end{array}$ & $\begin{array}{c}M_{\mathrm{w}} / M_{\mathrm{n}} \\
(\mathrm{GPC})\end{array}$ & $\begin{array}{c}\text { aldehyde } \\
\text { content/\% }\end{array}$ \\
\hline $\begin{array}{c}\text { poly }\left(\left[\mathrm{Me}_{2} \mathrm{Im}\right]\left[\mathrm{BF}_{4}\right]\right) \\
\text { poly }\left(\left[\mathrm{Me}_{2} \mathrm{Im}\right]\left[\mathrm{BF}_{4}\right]-\text { alt }-\mathrm{BzA}\right)\end{array}$ & black & 19.8 & 1.12 & - \\
poly $\left(\left[\mathrm{Me}_{2} \mathrm{Im}\right]\left[\mathrm{BF}_{4}\right]-\right.$ alt -pMeBzA $)$ & red & 20.3 & 1.29 & 41 \\
poly $\left(\left[\mathrm{Me}_{2} \mathrm{Im}\right]\left[\mathrm{BF}_{4}\right]-\right.$ alt-pMeOBzA $)$ & green & 5.5 & 1.75 & 50 \\
poly $\left(\left[\mathrm{Me}_{2} \mathrm{Im}\right]\left[\mathrm{BF}_{4}\right]-\right.$ alt-pClBzA $)$ & purple & 9.0 & 1.31 & 43 \\
\hline
\end{tabular}

Table S3. Copolymers of $\left[\mathrm{Me}_{2} \mathrm{Im}\right]\left[\mathrm{BF}_{4}\right]$ and pClBzA (for Figure 4B)

\begin{tabular}{ccccc}
\hline polymer & line & $\begin{array}{c}M_{\mathrm{n}} \\
(\mathrm{GPC}) \\
\times 10^{-3}\end{array}$ & $\begin{array}{c}M_{\mathrm{w}} / M_{\mathrm{n}} \\
(\mathrm{GPC})\end{array}$ & $\begin{array}{c}\text { aldehyde } \\
\text { content/\% }\end{array}$ \\
\hline poly $\left(\left[\mathrm{Me}_{2} \mathrm{Im}\right]\left[\mathrm{BF}_{4}\right]-\right.$ alt-pClBzA$)$ & red & 10.8 & 1.28 & 43 \\
poly $\left(\left[\mathrm{Me}_{2} \mathrm{Im}\right]\left[\mathrm{BF}_{4}\right]-c o-\mathrm{pClBzA}\right)$ & green & 12.4 & 1.26 & 37 \\
poly $\left(\left[\mathrm{Me}_{2} \mathrm{Im}\right]\left[\mathrm{BF}_{4}\right]-c o-\mathrm{pClBzA}\right)$ & blue & 11.5 & 1.21 & 21 \\
\hline
\end{tabular}

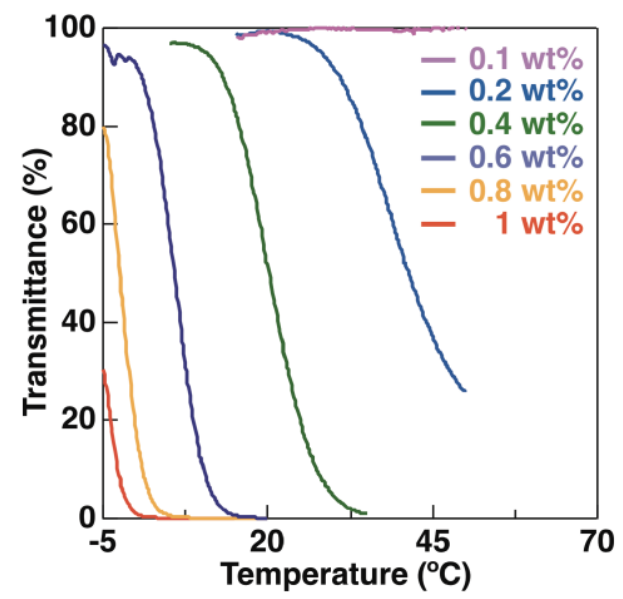

Figure S4. Turbidity measurements of acetone solutions of poly([ $\left.\mathrm{Me}_{2} \mathrm{Im}\right]\left[\mathrm{BF}_{4}\right]$-alt-pClBzA$)$ $\left[M_{\mathrm{n}}(\mathrm{GPC})=9.0 \times 10^{3}, M_{\mathrm{w}} / M_{\mathrm{n}}(\mathrm{GPC})=1.31\right.$, aldehyde content $=43 \%$ for precursor copolymer $]$ with different concentrations (scan rate: $1^{\circ} \mathrm{C} / \mathrm{min}$, heating) 

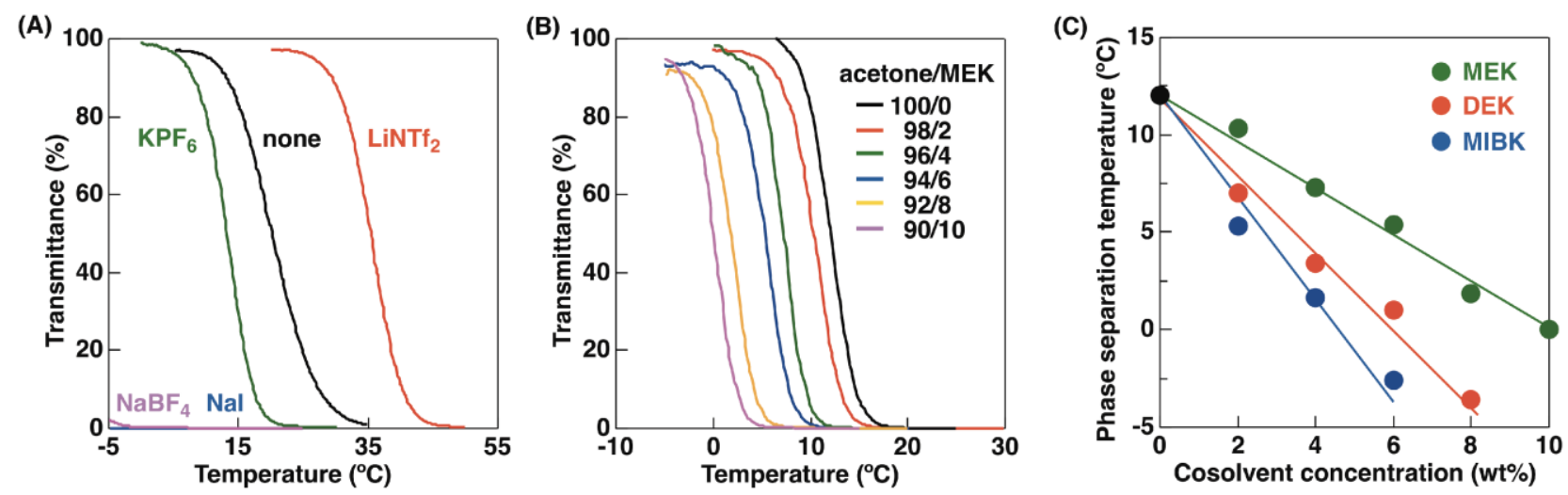

Figure S5. (A) Effects of the additional salts $(2.0 \mathrm{mM})$ on the thermosensitivity of $\operatorname{poly}\left(\left[\mathrm{Me}_{2} \mathrm{Im}\right]\left[\mathrm{BF}_{4}\right]\right.$-alt-pClBzA $)\left[M_{\mathrm{n}}(\mathrm{GPC})=9.0 \times 10^{3}, M_{\mathrm{w}} / M_{\mathrm{n}}(\mathrm{GPC})=1.31\right.$, aldehyde content $=$ $43 \%$ for precursor copolymer] (scan rate: $1{ }^{\circ} \mathrm{C} / \mathrm{min}$, heating; $0.4 \mathrm{wt} \%$ polymer) in acetone, (B) turbidity measurements of $0.8 \mathrm{wt} \%$ acetone/MEK solutions of poly([MeIm] $\left[\mathrm{BF}_{4}\right]-$ alt-pClBzA) $\left[M_{\mathrm{n}}(\mathrm{GPC})=10.6 \times 10^{3}, M_{\mathrm{w}} / M_{\mathrm{n}}(\mathrm{GPC})=1.31\right.$, aldehyde content $=43 \%$ for precursor copolymer $]$ (scan rate: $1{ }^{\circ} \mathrm{C} / \mathrm{min}$, cooling), and (C) effects of additional ketones [MEK (green line), DEK (red line), and MIBK (blue line)] on phase separation temperature.

Note for Figure S5A: The effects of additional salts may be complex because they would induce an anion exchange reaction.

Note for Figure S5B and S5C: The phase separation temperature changed depending on the amounts and structures of additional ketones. First, methyl ethyl ketone (MEK) was used as a solvent instead of acetone; however, poly $\left(\left[\mathrm{Me}_{2} \mathrm{Im}\right]\left[\mathrm{BF}_{4}\right]-\right.$ alt-pClBzA$)$ was insoluble in MEK in the whole temperatures and concentrations range examined. The result indicates that the solubility of the alternating copolymer considerably differs depending on the structure of the ketone. Thus, MEK was used in conjunction with acetone. The phase separation temperature of the alternating copolymer decreased with an increased amount of additional MEK (Figure S5B) at a ratio of approximately $1.25^{\circ} \mathrm{C}$ per $1 \mathrm{wt} \%$ MEK (green symbols in Figure S5C). In addition, the influence of the structures of the additional ketones was investigated with diethyl ketone (DEK) and methyl isobutyl ketone (MIBK). As a result, the cloud point decreased at ratios of $1.9^{\circ} \mathrm{C}$ and $2.4{ }^{\circ} \mathrm{C}$ per 1 wt\% DEK and MIBK, respectively (red and blue symbols in Figure S5C). The results indicate that the solubility of the alternating copolymers deceased upon the addition of ketones more hydrophobic than acetone. 
Table S4. Solubility characteristics of alternating copolymers of ionic liquid moieties with different counteranions and $\mathrm{pClBzA}^{a}$

\begin{tabular}{|c|c|c|c|c|c|c|c|c|c|c|c|c|}
\hline \multirow{3}{*}{$\begin{array}{l}X= \\
R=\end{array}$} & \multicolumn{12}{|c|}{$[\mathrm{RIm}][\mathrm{X}]-$ alt-pClBzA } \\
\hline & \multicolumn{3}{|c|}{$\mathrm{Cl}$} & \multicolumn{3}{|c|}{$\mathrm{BF}_{4}$} & \multicolumn{3}{|c|}{$\mathrm{SbF}_{6}$} & \multicolumn{3}{|c|}{$\mathrm{NTf}_{2}$} \\
\hline & $\mathrm{Me}$ & $\mathrm{Me}_{2}$ & $\mathrm{Bu}$ & $\mathrm{Me}$ & $\mathrm{Me}_{2}$ & $\mathrm{Bu}$ & $\mathrm{Me}$ & $\mathrm{Me}_{2}$ & $\mathrm{Bu}$ & $\mathrm{Me}$ & $\mathrm{Me}_{2}$ & $\mathrm{Bu}$ \\
\hline DMSO & $\mathrm{S}$ & $\mathrm{S}$ & $\mathrm{S}$ & $\mathrm{S}$ & $\mathrm{S}$ & $\mathrm{S}$ & $\mathrm{S}$ & $\mathrm{S}$ & $\mathrm{S}$ & $\mathrm{S}$ & $\mathrm{S}$ & $\mathrm{S}$ \\
\hline water & $\mathrm{S}$ & $\mathrm{S}$ & $\mathrm{S}$ & $\mathrm{U}$ & $\mathrm{U}$ & I & $\mathrm{S}$ & I & I & I & I & I \\
\hline methanol & $\mathrm{S}$ & S & S & I & I & S & I & I & S & $S$ & S & $S$ \\
\hline ethanol & $\mathrm{S}$ & $\mathrm{S}$ & $\mathrm{S}$ & I & $\mathrm{I}$ & $\mathrm{U}$ & I & I & I & $\mathrm{U}$ & I & $\mathrm{U}$ \\
\hline acetone & I & I & I & $\mathrm{L}$ & $\mathrm{L}$ & S & I & $\mathrm{L}$ & S & S & S & S \\
\hline THF & I & I & I & I & I & I & I & I & I & $\mathrm{L}$ & $\mathrm{L}$ & $\mathrm{S}$ \\
\hline chloroform & I & I & $\mathrm{L}$ & I & I & $\mathrm{I}$ & $\mathrm{I}$ & $\mathrm{I}$ & $\mathrm{I}$ & $\mathrm{I}$ & $\mathrm{I}$ & I \\
\hline DCM & I & I & I & I & $\mathrm{U}$ & $\mathrm{L}$ & I & I & I & I & I & S \\
\hline toluene & I & I & I & I & I & I & I & I & I & I & I & I \\
\hline
\end{tabular}

${ }^{\text {a }}$ S: soluble, I: Insoluble, U: UCST-type phase separation, L: LCST-type phase separation; 1 wt\% solutions. Red letter: change in solubility from a homopolymer with the corresponding ionic liquid-type structures.

Note for Table S4: The alternating copolymers containing conjugated aldehydes exhibited different dissolution behavior from that of homopolymers with corresponding ionic liquid-type moieties in various solvents. The solubilities of alternating copolymers carrying $\mathrm{BF}_{4}^{-}$or $\mathrm{NTf}_{2}^{-}$as the counteranions in some solvents was different from that of the homopolymer (red letters in Table S4, whereas the solubility of the $\mathrm{Cl}^{-}$or $\mathrm{SbF}_{6}^{-}$-containing copolymers was similar in the examined solvents. For example, the alternating copolymer possessing $[\mathrm{MeIm}]\left[\mathrm{NTf}_{2}\right]$ units as ionic liquid-type moieties underwent LCST-type phase separation in THF (Figure S6A) unlike the homopolymer insoluble in THF. The increase in hydrophobicity of the copolymers because of the introduction of the alternatingly arranged aldehydes moieties is likely responsible for the change in solubility in the solvents. 

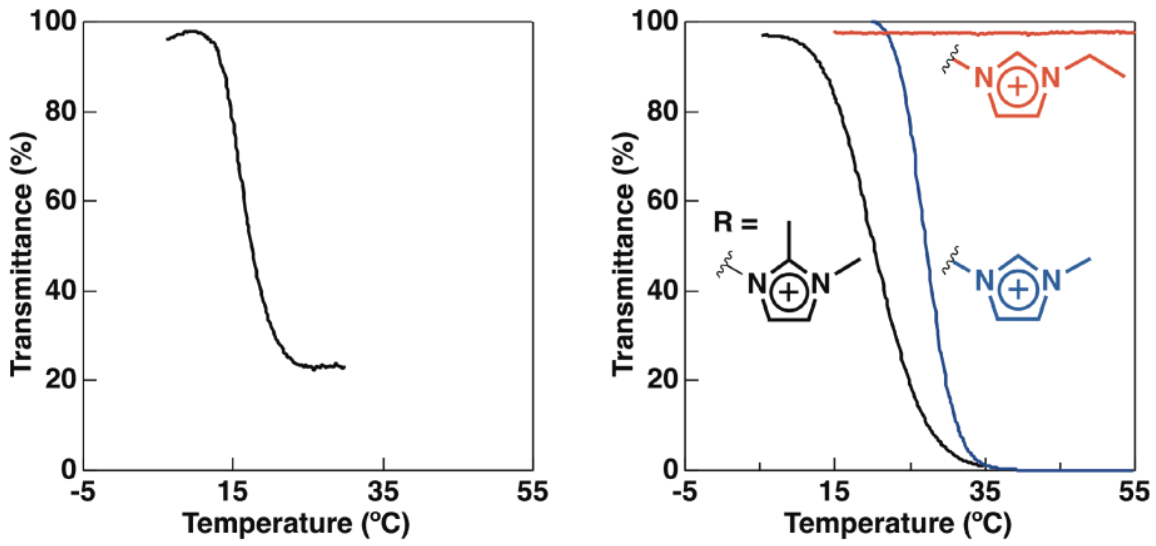

Figure S6. Turbidity measurements of (A) $1 \mathrm{wt} \%$ THF solution of poly([MeIm] $\left[\mathrm{NTf}_{2}\right]-$ alt-pClBzA) $\left[M_{\mathrm{n}}(\mathrm{GPC})=10.8 \times 10^{3}, M_{\mathrm{w}} / M_{\mathrm{n}}(\mathrm{GPC})=1.28\right.$, aldehyde content $=43 \%$ for precursor copolymer $]$ and (B) $0.4 \mathrm{wt} \%$ acetone solutions of poly([R][BF 4$]$-alt-pClBzA) with different cations $\left(\mathrm{R}=\mathrm{Me}_{2} \mathrm{Im}\right.$ (black line), MeIm (blue line), and EtIm (red line)).

Note for Figure S6B: The imidazolium rings and aldehyde substituents were also responsible for the LCST-type phase separation behavior in acetone. The alternating copolymer with $[\mathrm{MeIm}]\left[\mathrm{BF}_{4}\right]$ exhibited LCST-type phase separation behavior in acetone (Figure S6B, blue line). Interestingly, the phase separation behavior was sharper than that of the copolymer having the $\left[\mathrm{Me}_{2} \mathrm{Im}\right]\left[\mathrm{BF}_{4}\right]$ moieties. However, the copolymer possessing the $[\mathrm{EtIm}]\left[\mathrm{BF}_{4}\right]$ moieties, which is an isomer of $\left[\mathrm{Me}_{2} \mathrm{Im}\right]$ with a hydrogen atom at the 2-position, did not undergo the LCST-type phase separation in the whole temperatures range examined (Figure S6B, red line). The result indicates that the substituents of the imidazolium rings influence the solubility of the alternating copolymers in acetone.

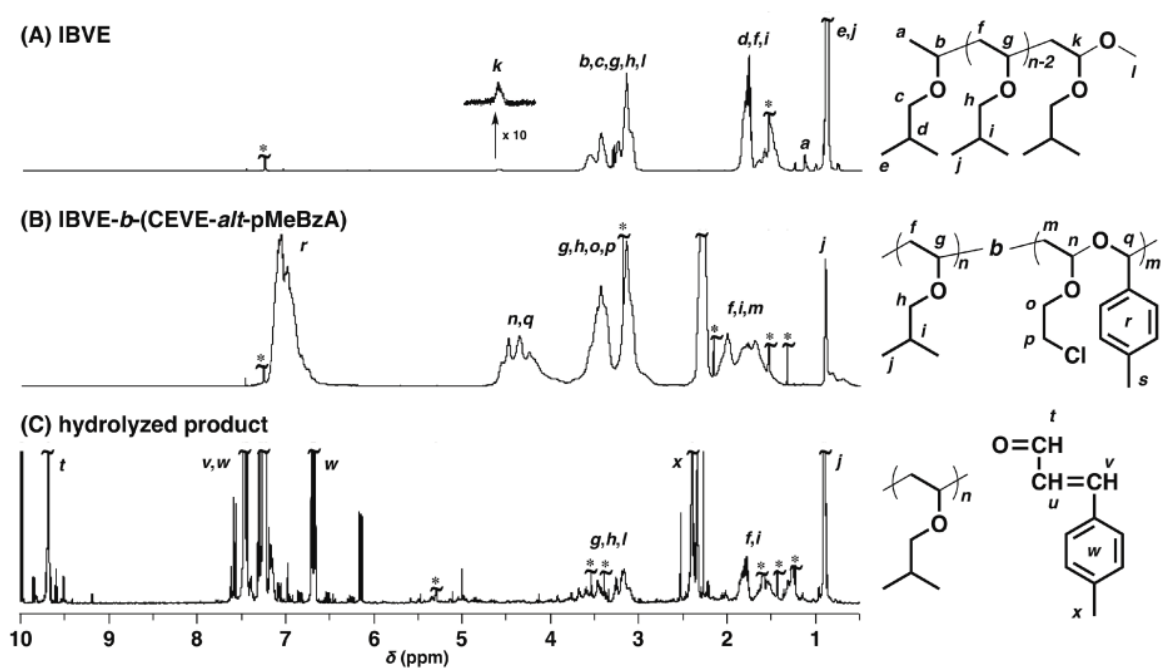

Figure S7. ${ }^{1} \mathrm{H}$ NMR spectra of (A) poly(IBVE) $\left[M_{\mathrm{n}}(\mathrm{GPC})=5.5 \times 10^{3}, M_{\mathrm{w}} / M_{\mathrm{n}}(\mathrm{GPC})=1.08\right]$, (B) poly(IBVE)- $b$-poly (CEVE-alt-pMeBzA) $\left[M_{\mathrm{n}}(\mathrm{GPC})=17.5 \times 10^{3}, M_{\mathrm{w}} / M_{\mathrm{n}}(\mathrm{GPC})=1.63\right.$, aldehyde content $=47 \%$ ], and $(\mathrm{C})$ the hydrolysis product of the copolymer in $\mathrm{CDCl}_{3}$ at $30{ }^{\circ} \mathrm{C}$ [hydrolysis conditions: $0.50 \mathrm{M}$ aqueous $\mathrm{HCl}-1,2$-dimethoxyethane at $30^{\circ} \mathrm{C}$ for $2 \mathrm{~h} ; 0.50 \mathrm{wt} \%$ polymer solution]. * solvent, acetone, methanol, water, grease, and TMS. 


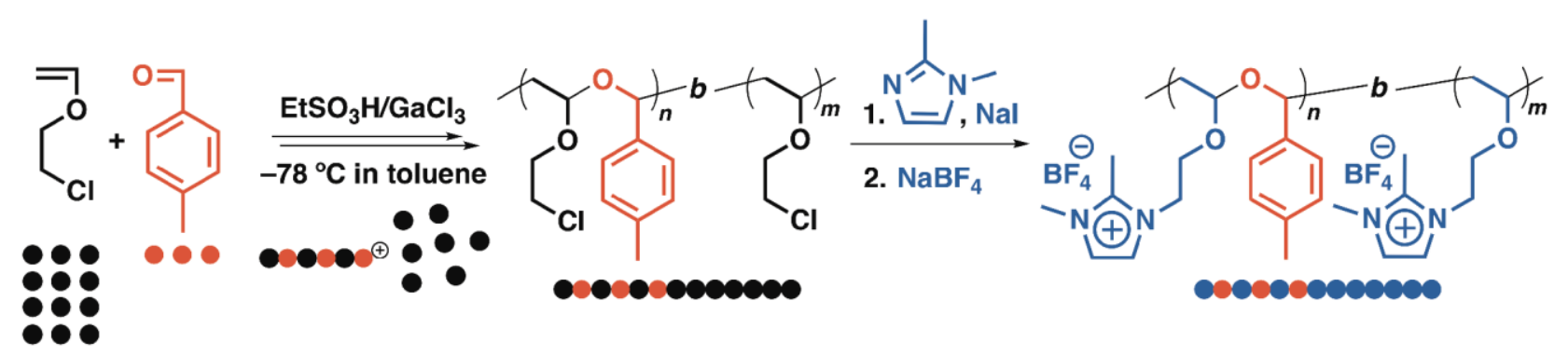

Scheme S2. One-shot synthesis of a block copolymer consisting of poly(CEVE) and poly(CEVE-alt-pMeBzA) segments.
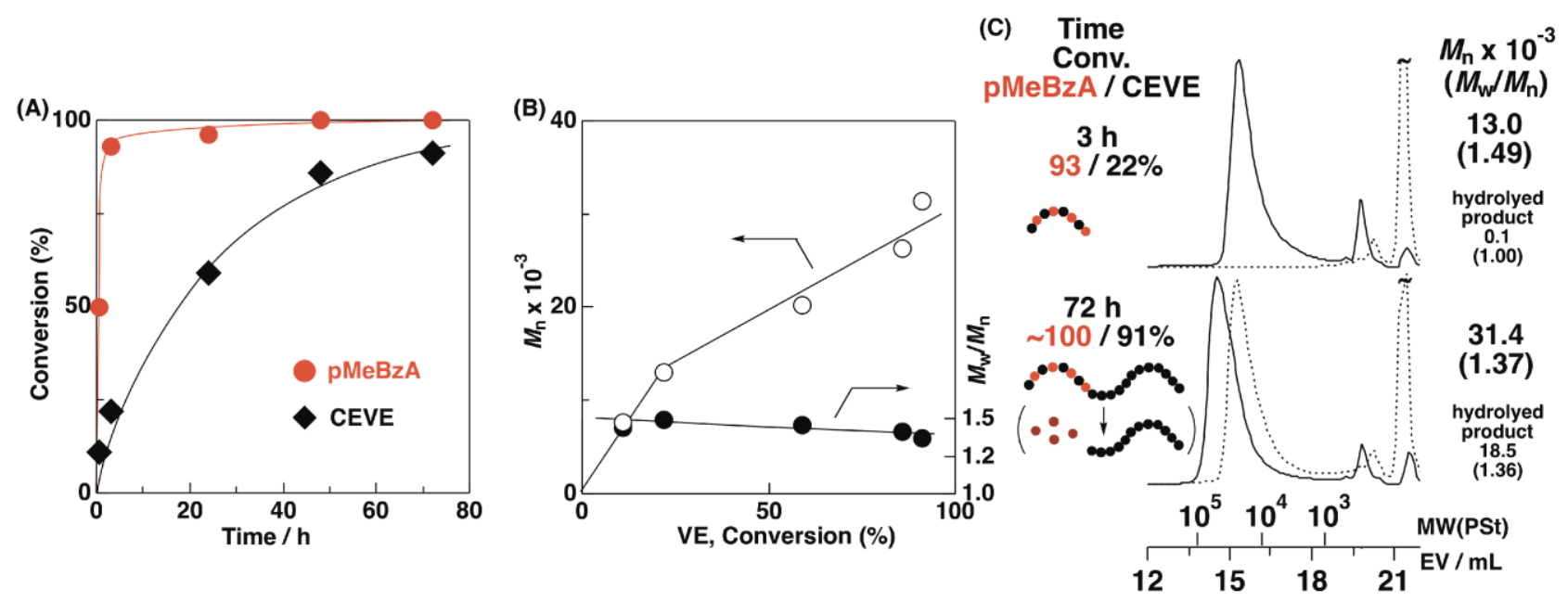

Figure S8. (A) Time-conversion curves, (B) $M_{\mathrm{n}}$ and $M_{\mathrm{w}} / M_{\mathrm{n}}$ for polymer peaks, and (C) MWD curves of products obtained by copolymerization of CEVE with pMeBzA (solid curves) and the hydrolysis product (dotted curve) (polymerization conditions: $[\mathrm{CEVE}]_{0}=2.0 \mathrm{M},[\mathrm{pMeBzA}]_{0}=0.40$ $\mathrm{M},\left[\mathrm{EtSO}_{3} \mathrm{H}\right]_{0}=4.0 \mathrm{mM},\left[\mathrm{GaCl}_{3}\right]_{0}=4.0 \mathrm{mM},[1,4$-dioxane $]=1.0 \mathrm{M}$ in toluene at $-78{ }^{\circ} \mathrm{C}$; hydrolysis conditions: $0.50 \mathrm{M}$ aqueous $\mathrm{HCl}-1,2$-dimethoxyethane at $30{ }^{\circ} \mathrm{C}$ for $2 \mathrm{~h}$; $0.50 \mathrm{wt} \%$ polymer solution).

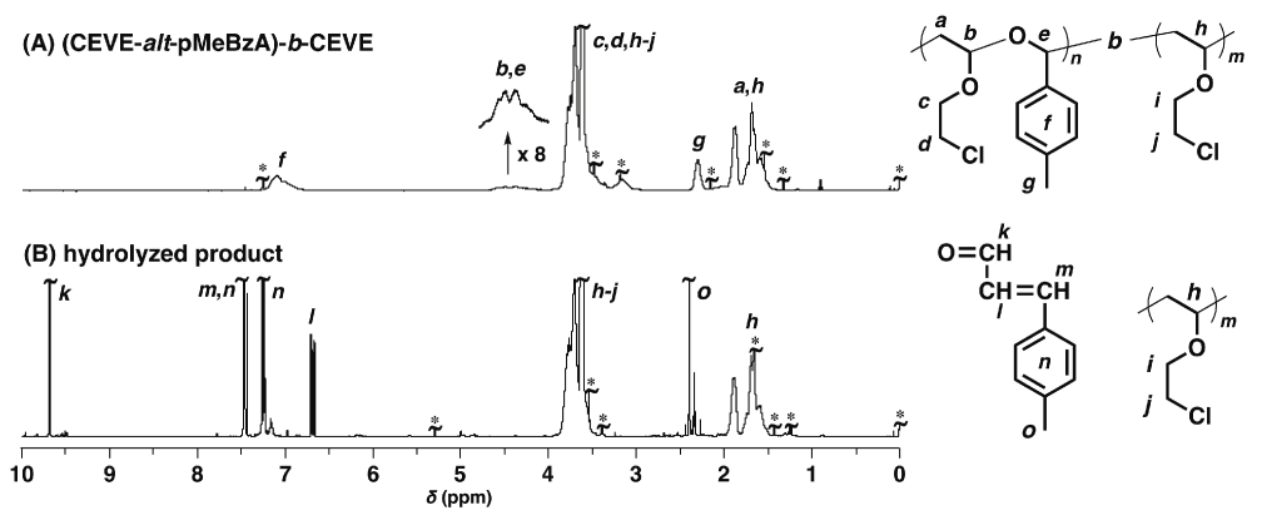

Figure S9. ${ }^{1} \mathrm{H}$ NMR spectra of (A) poly(CEVE-alt-pMeBzA)- $b$-CEVE $\left[M_{\mathrm{n}}(\mathrm{GPC})=29.9 \times 10^{3}\right.$, $M_{\mathrm{w}} / M_{\mathrm{n}}(\mathrm{GPC})=1.37$, aldehyde content $\left.=16 \%\right]$ and $(\mathrm{B})$ its hydrolysis product in $\mathrm{CDCl}_{3}$ at $30{ }^{\circ} \mathrm{C}$ [hydrolysis conditions: $0.50 \mathrm{M}$ aqueous $\mathrm{HCl}-1$,2-dimethoxyethane at $30{ }^{\circ} \mathrm{C}$ for $2 \mathrm{~h} ; 0.50 \mathrm{wt} \%$ polymer solution]. * solvent, acetone, methanol, water, grease, and TMS. 
Note for Scheme S2 and Figures S8 and S9: One-shot copolymerization of CEVE with a small amount of pMeBzA was effective for synthesis of block copolymers consisting of a poly(CEVE-alt-pMeBzA) segment and a poly(CEVE) segment (Scheme S2). The cationic copolymerization was conducted at a large feed ratio of CEVE/pMeBzA $\left(5 / 1 ;[\mathrm{CEVE}]_{0}=2.0 \mathrm{M}\right.$, $[\mathrm{pMeBzA}]_{0}=0.40 \mathrm{M}$ ) using the $\mathrm{EtSO}_{3} \mathrm{H} / \mathrm{GaCl}_{3}$ initiating system in the presence of 1,4-dioxane as an added base in toluene at $-78^{\circ} \mathrm{C}$ (Figure S8). The copolymerization proceeded in an alternating manner until quantitative consumption of pMeBzA. The alternating propagation even at the large $\mathrm{CEVE} / \mathrm{pMeBzA}$ ratio coincided with the monomer reactivity ratios, which are close to zero, of these monomer. ${ }^{\mathrm{S} 1}$ pMeBzA was almost consumed within $3 \mathrm{~h}$, yielding an alternating copolymer with a $45 \%$ aldehyde content (the upper curves in Figure S8C). The remaining CEVE monomer was quantitatively consumed within approximately $70 \mathrm{~h}$, resulting in the generation of a copolymer consisting of the alternating segment and a poly(CEVE) segment (the upper curves in Figure S8C). The product obtained via the acid hydrolysis reaction of the block copolymer had an MW value of $18.5 \times 10^{3}$ (the bottom curves in Figure S8C). These results correspond to the MW value of the poly(CEVE) segment formed after the consumption of pMeBzA. In addition, the ${ }^{1} \mathrm{H}$ NMR spectrum of the hydrolysis products had peaks assigned to the cinnamaldehyde derivative and poly(CEVE) (Figure S9), indicating that the degradable poly(CEVE-alt-pMeBzA) segment of the block copolymer decomposed.

S1. Kawamura, M.; Kanazawa, A.; Kanaoka, S.; Aoshima, S. Sequence-controlled degradable polymers by controlled cationic copolymerization of vinyl ethers and aldehydes: precise placement of cleavable units at predetermined positions. Polym. Chem. 2015, 6, 4102-4108. 


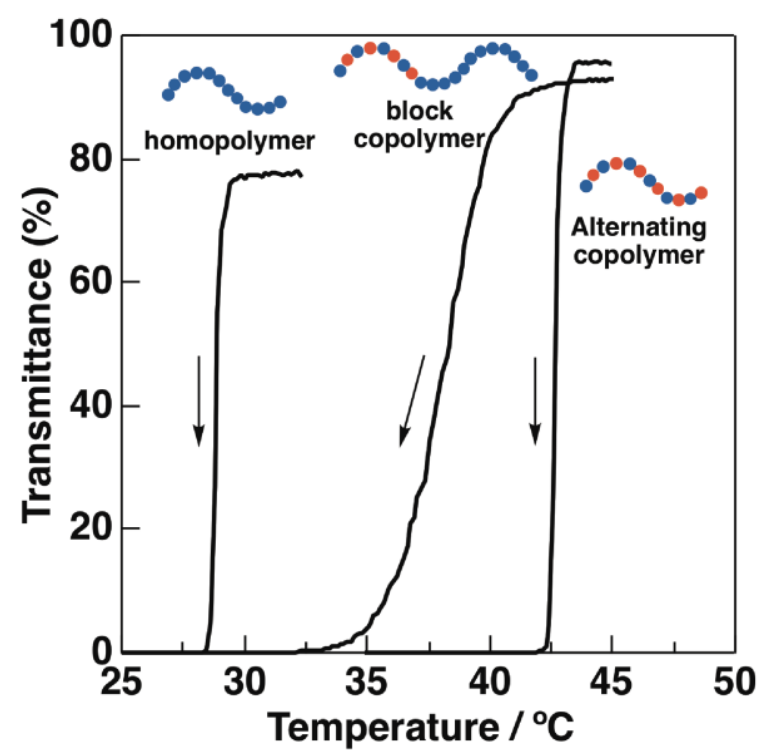

Figure S10. Thermosensitive behavior for $4 \mathrm{wt} \%$ aqueous solutions of poly([ $\left.\left.\mathrm{Me}_{2} \operatorname{Im}\right]\left[\mathrm{BF}_{4}\right]\right)$ $\left[M_{\mathrm{n}}(\mathrm{GPC})=19.8 \times 10^{3}, \quad M_{\mathrm{w}} / M_{\mathrm{n}}(\mathrm{GPC})=1.12\right.$ for precursor copolymer $]$, poly $\left(\left[\mathrm{Me}_{2} \operatorname{Im}\right]\left[\mathrm{BF}_{4}\right]-\right.$ alt-pMeBzA) $-b$-poly $\left(\left[\mathrm{Me}_{2} \mathrm{Im}\right]\left[\mathrm{BF}_{4}\right]\right)\left[M_{\mathrm{n}}(\mathrm{GPC})=31.4 \times 10^{3}, M_{\mathrm{w}} / M_{\mathrm{n}}(\mathrm{GPC})=\right.$ 1.37 , aldehyde content $=16 \%$ for precursor copolymer], and poly $\left(\left[\mathrm{Me}_{2} \mathrm{Im}\right]\left[\mathrm{BF}_{4}\right]\right.$-alt-pMeBzA$)$ $\left[M_{\mathrm{n}}(\mathrm{GPC})=23.2 \times 10^{3}, M_{\mathrm{w}} / M_{\mathrm{n}}(\mathrm{GPC})=1.31\right.$, aldehyde content $=49 \%$ for precursor copolymer $]$.

Note for Figure S10: The block copolymer that consisted of poly([Me $\left.2 \mathrm{Im}]\left[\mathrm{BF}_{4}\right]\right)$ and poly $\left(\left[\mathrm{Me}_{2} \mathrm{Im}\right]\left[\mathrm{BF}_{4}\right]\right.$-alt-pMeBzA) segments underwent UCST-type phase separation in water at temperatures lower than that of the corresponding alternating copolymer. For the turbidity measurements of $4 \mathrm{wt} \%$ aqueous solutions (Figure S10), the block copolymer exhibited UCST-type phase separation behavior at a temperature between the phase separation temperature of the $\left[\mathrm{Me}_{2} \mathrm{Im}\right]\left[\mathrm{BF}_{4}\right]$ homopolymer $\left(28{ }^{\circ} \mathrm{C}\right)$ and that of poly([ $\left.\mathrm{Me}_{2} \mathrm{Im}\right]\left[\mathrm{BF}_{4}\right]-$ alt-pMeBzA$)\left(42{ }^{\circ} \mathrm{C}\right)$. In addition, the phase separation occurred in a relatively broad temperature range. These results suggest that the block copolymer does not aggregate at the phase separation temperatures of each segment. Instead, the broad phase separation indicated that the aggregation of the alternating segments most likely gradually occurred in association with the aggregation of the $\left[\mathrm{Me}_{2} \mathrm{Im}\right]\left[\mathrm{BF}_{4}\right]$ segment. 


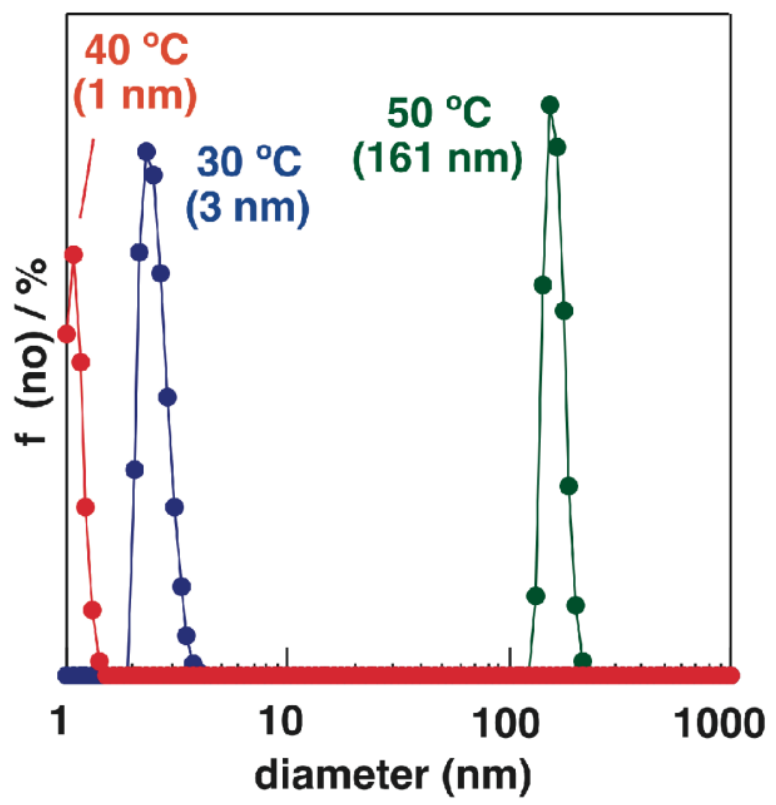

Figure S11. DLS measurement for 0.3 wt $\%$ acetone solution of poly(IBVE)- $b$-poly([ $\left.\mathrm{Me}_{2} \mathrm{Im}\right]\left[\mathrm{BF}_{4}\right]-$-alt-pMeBzA) $\quad[$ the ratio of poly(IBVE) segment/poly([Me $2 \mathrm{Im}]\left[\mathrm{BF}_{4}\right]$-alt-pMeBzA) segment was 50/200; $M_{\mathrm{n}}(\mathrm{GPC})=17.5 \times 10^{3}$, $M_{\mathrm{w}} / M_{\mathrm{n}}(\mathrm{GPC})=1.63$, aldehyde content $=47 \%$ for precursor copolymer $]$ at 30 (blue), 40 (red), or 50 (green) ${ }^{\circ} \mathrm{C}$. 